Portland State University

PDXScholar

1973

\title{
Selected Attitudes and Values of Young Adults in Northern Sierra Leone
}

Fatu Y. Kamara

Portland State University

Follow this and additional works at: https://pdxscholar.library.pdx.edu/open_access_etds

Part of the Social Work Commons

Let us know how access to this document benefits you.

\section{Recommended Citation}

Kamara, Fatu Y., "Selected Attitudes and Values of Young Adults in Northern Sierra Leone" (1973).

Dissertations and Theses. Paper 1733.

https://doi.org/10.15760/etd.1732

This Thesis is brought to you for free and open access. It has been accepted for inclusion in Dissertations and Theses by an authorized administrator of PDXScholar. Please contact us if we can make this document more accessible: pdxscholar@pdx.edu. 
SELECTED ATTITUDES AND VALUES OF YOUNG ADULTS

IN NORTHERN SIERRA LEONE

by

FATU Y. KAMARA

A report submitted in partial fulfillment of the requirements for the degree of

MASTER OF

SOCIAL WORK

Port land State University

1973 
TABLE OF CONTENTS

CHAPTER

I INTRODUCTION .................. 1

II COLONIZATION AND BRITISH RULE IN SIERRA LEONE • • • 3

Court decision in Black Poor Committee 1772.... 3

Difficulty of settling in Freedom City ...... 4

Establishment of Government in New Freedom C1ty. . 5

The British Hut Tax War. . . . . . . . 8

III TRADITIONAL NORTHERN SIERRA LEONE FAMILY •. . . . . 14

Family Composition ............. 14

Marrlage Ceremony. . . . . . . . . . 15

Polygynist Practices .............. 18

Selection of spouses .............. 19

Position of wives in the order of marriage.... 20

Grounds for divorce.............. 21

Secret socleties ............... 22

Formal or Western Education. ......... 23

IV METHODOLOGY. . . . . . . . . . . . . 25

V ANALYS IS OF RESEARCH DATA. . . . . . . . . . 27

vI CONCLUSION ................ 55

REFERENCES CITED . . . . . . . . . . . . . . . . 59 


\section{INTRODUCTION}

The Republic of Slerra Leone is situated on the Northwest African coast and occuples an area of 28,000 square miles. It is bounded on the north and the east by the Republic of Guinea, on the south by Liberia, and on the west by the Atlantic Ocean. It has a population of 2.5 million people, comprised of thirteen tribes. The main tribal groupings are the Limbas, Mendes, Temes, and Creoles. With the exception of the descendants of former slaves residing in the Colony area, most of the occupants of the interior are belleved to have emigrated into sierra Leone from neighboring West African territories at an earlier period. Largely ilifterate and primitive in some aspects, these interior tribes rely mainly on subsistence farming. They contrast sharply with the settlers or Creoles who reside in the colony area. The Creoles are highly 11terate, "civilized" and practice western culture and traditions more than any other group in slerra Leone.

Due to British policy and the obvious dislike of European influence by the inhabitants of the hinterland, it took a long time before development programs could be instituted in that part of the country. In fact, the northern tribes, the subject of my paper, because of their stronger traditional opposition to western culture lagged behind in improvement and social reforms. For instance, while schools were opened in the colony area in 1787, and in the southern and eastern provinces in 1906 , the north did not get its first high 
school unt11 1950.

In the first part of this work I Intend to examine the social institutions of the Northerners with particular emphas is on their family system. I shall devote the second part to analyzing the changing attitudes of 11terate and 1111 terate Sierra Leoneans from the North towards family relationships. I shall also explain how far the assimilation of European culture by these people has affected the traditional African Soclety. In my conclusion, I shall make recommendations and suggestions on how the two cultures, Western and African, can be used to benefit the inhabitants of the north. 


\section{COLONIZATION AND BRITISH RULE IN SIERRA LEONE}

The Republic of Slerra Leone is located along the west Coast of Africa. It is equal in size to South Carolina and has a population of 2.5 million people. It is alleged to have received its name from a Portuguese explorer, Pedro Da Cintra, who reached that part of Africa in 1462. Hearing the sound of noises in the neighboring mountains from the harbor, and thinking that 1 lons resided in those mountains, he therefore called the place Slerra Leone, meaning in Portuguese, 11 on mountains. Other historlans however, feel that the country got its name from "Its wild looking, Leonine Mountains".

In June 1772, Judge Mansfleld delivered a famous court decision in England, in the Somerset case, in which he maintained that any slave who stepped on English soll automatically became a free man. The Immediate effect of Mansfield's judgment was to increase the number of blacks in England. Several came from all sections of the new world in search of freedom under the British flag. Most of the arrivals were poor, jobless, destitute and uncared for.

Consequently, a "Black Poor Comittee" was formed by some British citizens, under the chairmanshlp of James Hanway, to watch over the social welfare of the blacks. ${ }^{2}$ Acting upon the recommendation of

I Christopher Fyfe, A History of Slerra Leone (London: Oxford University Press, 1962), p. 1.

$$
2 \text { Ibid, p. } 14 \text {. }
$$


Dr. Smeathman, a Swedish botanist studying at the time in the Banana Is lands near Slerra leone, the Committee decided to repatriate the ever increasing number of blacks in London to Slerra Leone.

The first group which arrived in February 1787, consisted of 450 blackmen, 41 blackwomen, 70 white prostitutes, 38 officials and one private passenger. They occupled a piece of land which had been bought by Committee officials from one of the local chlefs. The settlers named their new settlement Freedom City, syrabolic of that freedom which had eluded them for many years.

Two months later, natives attacked and destroyed the settlement, mainly because they feared that the new arrivals would interfere with the slave trade, their main source of revenue. The settlers in fear of subsequent attacks abandoned the entire settlement and headed for different places near what was before known as "Freedom City". Faced with an unsuccessful first attempt, members of the Black Poor Committee disbanded and formed a new group called the Slerra Leone Company, whose major objective was to rejuvenate the abandoned settlement and make provisions for subsequent arrivals.

During the American War of Independence, a number of blacks and whites supported the British government against the rebelilous colonists. At the end of the war, most of the loyalists feared reprisals from the victorlous Americans and therefore, requested to follow the defeated British forces. Great Britain decided to send these loyalists to Halifax, Nova Scotia in Canada. ${ }^{3}$ Finding the place to be extremely cold and faced with insufficient land to grow crops, the black loyalists petitioned the 
British government that they be sent to Africa. A group consisting of nearly 1,000 blacks was taken to Sierra Leone in 1792 by British officials. The new arrivals were known as Nova scotians because they had previously resided in that place. Shortly thereafter, another group of settlers from Jamaica, the Maroons, were brought to Slerra Leone by Great Britain.

During the Napoleonic Wars, the Slerra Leone Company's colony fell victim to French sallors. They attacked it, robbed the settlers, and destroyed what they could not take to their ships. Also, sporadic attacks by natives and the alleged rebellious nature of some of the settlers contributed to the British government's decision to take control of the colony. In 1808 , it was declared a crown colony. 4

For many years, British influence was limited only to the colony area. Most of the interior of Sierra Leone where the bulk of the people resided, was untouched. In 1890 , the British officials in Freedom City, which now came to be known as Freetown, began to sign trade agreements with the chiefs in the hinterland, and also to secure concessions from these chiefs to allow the British to arbitrate in the disputes with neighboring tribes. In 1894, S1r Frederick Cardew was appointed acting governor of the colony, and In 1895, he was made full governor. Prior to his confirmation as governor, he made an extensive tour into the heartland of Slerra Leone and on the basis of what he saw formulated a policy for the area. 5 The British by an Act of Proclamation in 1896,

4 Hassan B. Sisay, "Review of Liberia by Charles M. Wilson," Journal of Negro History, LVII (January 1972), p. 49.

5. J. Alldridge, The Sherbre and its Hinterland (London: Macmillan \& Co. Itd., 1901), pp. 165-281. 
declared a Protectorate in the hinterland without the knowledge and consent of the people. 6

Having thus created a protectorate, the British found it expedient to administer some form of control over the area clalmed. The protectorate was divided into five districts, Bandajuma, Keinadugu, Ronletta, Panguma and Karena. ${ }^{7}$ Each district was put under the command of an English offlcer with the title of "District Commissioner". The title of paramount chlef was conferred upon the most important chiefs within the districts. This was a departure from earlier times when ruling heads used the titles of "Kings", "Queens", or "Chiefs". The government wanted to emphasize that there was only one Queen, Queen Victoria of Great Britain, ruling the protectorate, and no other person was allowed royal titles. 8

The proclamation also introduced an ordinance that imposed como pulsory social reforms in the protectorate, removed oppression and scaled down the notorious slave traffic, that was now directed to the ports of Conakry in the controlled reglons of the French. Because of its emphasis on moral principles and respect for the fundamental human rights of liberty, and freedom from slavery and arbitrary arrest, it alienated the feelings of the chiefs. 9 The ordinance also reduced the

${ }^{6}$ Slerra Leone Royal Gazette, (August 1896).

${ }^{7}$ Christopher Fyfe, A History of Slerra Leone (London: Oxford Univers1ty Press, 1962), p. 542.

8 Ibld.

9T. J. Alldridge, The Sherbre and its Hinterland (London: Macmillan \& Co. Ltd., 1901), p. 302. 
powers of the chiefs and gave extensive judicial control to the young district commissioners in matters which before this time were handled by the chiefs. 10 The comissioners arbitrated in tribal disputes and in some instances even transcended their powers by interfering in chiefs' coronations, thus violating native customs and traditions.

For instance, in the district of Karena, the local chlef died in 1896, and a long period elapsed in which the natives mumbled and fumbled over the legal successor. After one and a half years of fruitless delay, the district commissioner intervened and unilaterally appointed a chlef of his own cholce.11

Some clauses in the ordinance relating to land tenure virtually gave the crown all lands in the protectorate. 12 A provision abolishing corporal punishment was interpreted by the chlefs as challenging a man's rights to beat his wife. This was incomprehensible to the chlefs as local laws and customs had given overwhelming power to husbands over their wives. There were also clauses that abolished every form of slavery, including the domestic type. The protectorate people therefore feared that reforms would be even more extensive. Rumors circulated that in the future, the British would stop chlefs from hearing "palava" and that the government would ban polygyny, a vital economic institution. 13

$10 \mathrm{~J}$. D. Hargreaves, "The Establishment of the Slerra Leone Protectorate and the Insurrection of 1898", Cambridge Historical Journal, X11 (1956), Pp. 63-64.

${ }^{11}$ Christopher Fyfe, A History of Sierra Leone (London: Oxford University Press, 1962), p. 553.

$12 \mathrm{H} . \mathrm{R} . \mathrm{F}$. Bourne, "Slerra Leone Troubles", Fortune, 70 (NS 64) p. 226.

${ }^{13}$ Christopher Fyfe, A History of Slerra Leone (London: Cxford University Press, 1962), p. 552. 
The event which however, increased the yawning gap of differences between the colony and the protectorate was the imposition of a tax by the British officials on everyone in the protectorate. A year's notice was given before levying the tax, which consisted of five shillings for every house of two rooms; while villages of less than twenty houses were exempted from the tax. 14

Govenor Cardew, in recommending the tax, was quite optimistic of its yielding good results, and on the whole, he was rather pleased with the way people were reacting to British rule:

The protectorate ordinance as far as I can ascertain is working smoothly and the authority and jurisdiction of the district commissioners is being felt and accepted. I gather this from unofficlal as well as offlcial sources, but of course, the crucial time will be when the House Tax is levied but with an adequate police force and a sufficlent complement of white officers, I have no apprehension as to the results. 15

But on the contrary, the people in the protectorate were not expectant of good results as Cardew had indicated to his Secretary of State in London. For the men employed to collect taxes were nelther honest, merclful, nor efficient. These were frontier policemen, who, In many instances were efther convicts or runaway slaves who had escaped to the colony. 16 They now came back with profound animosities and deep-seated vengeance to collect taxes from some of their former masters.

14 Robert Rotberg and A1I Mazrul, Protests And Power In Black Africa (New York: Oxford University Press, 1970), p. 172.

15 Ibid.

${ }^{16}$ Christopher Fyfe, A History of Sierra Leone (London: Oxford University Press, 1962), p. 580. 
In December 1894, the Slerra Leone Weekly News, and the Slerra Leone Times, featured articles on the lawless and wicked attitudes of the policemen towards their kith and kin. Allegations ranged from random murders and commando raids to the ravaging and looting of defenseless villagers. The papers also accused the policemen of forced labor by compelling the aborigines with klcks and blows, to carry their loads without wages. They allegedly robbed the villagers, seduced their wives, and humillated parents in front of their children.17 In addition to the trail of tears left by these inexperienced and ignorant agents of British imperialism, there were horrible atrocities perpetrated on the protectorate people by the English officials themselves. These took the form of punitive expeditions sent into the hinterland to deal with potential trouble causers. Many people lost their 11 ves and properties from these random forays.

These incldents and several others increased the suspicions and distrust which the peoples of the protectorate were gradually acquiring against British rule and justice. Hatred for everything European therefore took a new dimension and began to involve elements of militancy especially in Mende land where missionaries had made extensive inroads among the different tribes. ${ }^{18}$ The missionaries began to be suspected of spying on local chiefs and disclosing their findings to the British government. They were also accused of preaching false and harmelul doctrines to the native boys, especially those that encouraged them to

17 Robert Totberg and All Mazrul, Protests and power in Black Africa (Now York: Oxford University Press, 1970), pp. 179-180.

18 Missionary attacks were not very common in the North because there were few missionaries there and because of 1 ts strong Mus $11 \mathrm{~m}$ influence. The South was more appealing to the missionaries. 
their illiterate, pagan brothers and to revile the achievements of their ancestors. Such teachings threatened to break up the whole soclety, and many protectorate people vehemently opposed opening more missionary schools. The aloofness and suspicions of native people toward all European styles and customs accelerated when the missionarles began to refer to the highly respected "Porroh Soclety", as "devil worship". 19 These derogatory references toward one of their most sacred secret institutions was greatly resented.

In 1897, using the Hut Tax as a pretext, a group of chlefs from the protectorate drew up a petition and presented it to the Governor in Freetown. They expressed grave concern about the erosion of their judicial authority and the increased powers of the district commissioners. 20 They protested against the abolition of the slave trade, the activities of the frontier policemen, and finally revealed their inability to pay the house tax. To most people in the protectorate the tax was misunderstood, hence they deemed it unnecessary and redundant. One chlef oven remarked that it was Impossible that the Queen should lack money when her head was on every coin. 21 The chiefs also did not see what rights the government had to make them pay for their homes. To them, ylelding to the Hut Tax meant an abrogation of their rights to their houses. One other crucial point which most writers on Slerra leone history overlook, viz, Christopher Fyfe, Michael Crowder, Hirst and Isa Kamara, is the effect of the tax on the institution of chieftaincy. Since

${ }^{19}$ Christopher Fyfe, A History of Slerra Laone (London: Oxford University Press, 1962), p. 554.

$$
{ }^{20} \text { Ibid, Pp. } 542-545 \text {. }
$$

$21_{\text {Ibid, p. } 576 .}$ 
anclent times, chlefs traditionally accepted young girls from their subjects as wives. Some chiefs therefore ended up having seventy or more wives. Some of the important wives of the chiefs were provided with separate huts of their own. Accepting a tax levied on each hut was an economic challenge greater than the chlefs could cope with.

Besides the rulnous effects of the tax to the chiefs, many people Including tribal heads and prominent citizens of the protectorate interpreted the imposition of the tax as a signal for the degeneration of the one time powerful and flourishing British government. So common was this notion of a British death, that one Teme man was forced to remark, "her majesty was dead, therefore, England is in ruins. If not so, why should a government that was pensioning our Kings now tax the very Kings and their subjects." 22 Another opponent of the tax and English rule in the protectorate recommended what to him appeared a liveller and more humane way of exhibiting British power,

The English people must exhibit their greatness like God, by leading some crafts with biscuits, bread, salt meat, pork etc., annually to distribute them to the natives, and should not come to extract money from people who value five shi11ings as $f$ ive pounds. 23

In the midst of these confusions, European traders, and settlers, who now called themselves creoles, doubted whether the tax could be collected. They maintained that the people would take to the bush rather than pay, and that trade could be ruined. The British traders, alarmed at the frequent reports that the tax was affecting trade,

${ }^{22}$ A. B. C. Sibthorpe, The History of Slerra Lone (New York: Human1ties Press, 1971), p. 125.

${ }^{23}$ Ibid. 
resolved in April 1897, to ask that the tax which they had long opposed be repealed. The Secretary of state for the colonies, Joseph Chamberlain, was at first very sympathetic to their views. But when he received reports that these sane merchants were selling gun powder to the natives and encouraging them to rebel, he repudiated their demands.

Letters of protest and petitions against the tax and British rule in the protectorate were sent by chlefs to the Governor. One protest letter which epltomized all the grievances of the natives was sent to Captain Sharpe, District Commissioner of Port Loko, was signed by Bai Bureh, leader of the ant1-British forces in the protectorate, and four other chlefs. "They protested the English declaration of a protectorate in the interior and vehemently opposed the interference of British officials in their social customs and traditions. For instance, the chiefs complained about the abolition of slavery in the hinterland, the seizure of chlefs' lands, the downgrading of the power of the local authorities and the continuous alteration of their society by the "British strangers".

When Great Britain refused to 1 isten to their demands and concerns, Bai Bureh assembled his war boys in Port Loko and declared war against the British. After four years of fighting in which many people lost their lives and property, the native forces surrendered in 1898, and thereby paved the way for British occupation of the interior. In 1906, the British government built roads in the hinterland, opened the first high school at Bo, and extended the railway to Bauya and Rotifunk. In 1924, Great Britain drew up a constitution for Sierra leone and made provisions for elected black officials from the colony and protectorate 
areas to sit in the legislature. The 1947 constitution broadened black participation and increased the number of representatives to the legislature from the protectorate. In 1951, Slerra Leone became a self-governing state under the leadership of Milton Margal. Ten years later, it became an independent state within the British Commonwealth. Formal connections with the British crown ended in 1971, when the newly elected Prime Minister, Slaka Stevens, declared the state a republic. With this brief background, we shall turn now to a general description of the northern tribes in order to lay a basis for the study of their changing attitudes in relationshlp to the famlly. 


\section{THE TRADITIONAL NORTHERN FAMILY}

The Republic of Sierra Leone is divided into four sections, the north, south, east and west. My area study, the north, is the largest in size and the most thickly populated. It's area is about 15,000 square miles and it has a population of half a million people. It is occupied by Temnes, Limbas, Yalunkas, Lokos, Mandingos, Fullahs, and many other smaller tribes.

Since the north is located in the Savannah region, which is mainly grassland, many of its inhabitants are elther farmers or cattle ranchers. There are however, a small number of businessmen operating in big towns and trading centers 11 ke Maken1, Kabala, Port Loko and Lunsar.

The majority of the northerners are illiterate and practice Mosiem and African customs. Most of their social beliefs and institutions are the same, apart from minor differences in customary initiation and secret society procedures.

In the traditional northern famlly, the most important person is elther the father, grandfather or uncle. His authority over the family is supreme and largely unchallenged. As the head of the family, he is responsible for maintaining order, and this involves establishing his authority over his wives and chlldren, grandchildren, their wives and children. 24

24 Alba I. Zizzamin, The House Stands Firm: Family life in West Africa (Milwaukie: The Bruce Publishing Co., 1962), p. 54. 
Apart from the father, grandfather or uncle, there are other important traditional rulers in the north. Among the most important, is the Clan Chief. His dutles are very similar to those of the head of the family. But as a clan Chlef, he is primarily responsible to Interpret the customary laws and settle all disputes among his subjects. He is also to protect them in case of attack from the outside. The clan members in turn are to offer certain services to the Chief. For instance, they work on his farms, assist in the administration of the clan, and offer him their daughters as wives. 25

One of the most important institutions among the people of the north is marriage. This sometimes involves a long period of betrothal in which men will negotiate with frlends for a young baby about to be born. Other times the perlod of negotlations starts when young man sees a girl he would like to marry. After making secret visits to the girl's home, the male will reveal his marital intentions to his parents, who will then summon the whole family and ask that the issue be discussed. Generaliy, the discussion will center on the girl's parents, their soclal background, and what chances there are for the success of the marriage. Also, consideration is given to the girl's appearance, her behavior and association with other girls in the village. After these investigations, the family will decide on whether to support the proposed marriage or not. In many instances, the crucial decision is made by the father. It is not uncommon to find cases in which the boy's family approves of his cholce but because the father

${ }^{25}$ Alba I. Zizzamin, The House Stands F1rm: Family life in West Africa (Milwaukle: The Bruce Publishing Co., 1962), p. 59-60. For a detalled discussion of the African Clan system, see Chinna Achebe Things Fall Apart, (London: Oxford University Press, 1958). 
refuses to agree and the marriage proposal collapses. Sometimes, a compromise is achleved in which the father allows the son to retain his cholce and he in turn allows his father to select a second wife for him. 26

The selection of girls as wives involves a number of stages. In the first place, you have the engagement period in which different things are given to the girl's parents. The most common glfts are liquor, kola nuts, raphia, mats and palm wine. 27 In some cases, the would be husband wl11 offer his services on the farms of his future parents-in-law. After that, the prospective husband will continue to pay visits to his parentsIn-law unt 1 preparations are finalized for the wedding ceremony. Before this happens however, the boyfriend has to do a number of things. One of the most important parts of the wedding contract is the payment of a dowry price for hls bride. According to experts on African customs,

The dowry represents compensation and a homage to the power of the family chief, who then cedes to the groom a share of his authority over the young girl and consequently of his parental control over the children that will be born of her. 28

The brides price however, is reciprocal. If a groom pays an expensive dowry, her parents are expected to buy costly furniture and kitchen utensils for the couple.

${ }^{26}$ Alba I. Zizzamin, The louse Stands Firm: Family Life in West Africa (Milwaukle: The Bruce Publishing Co., 1962), p. 95.

27 M. McCulloch, Peoples of Sierra Leone (London: International African Institute, 1964), p. 58.

${ }^{28}$ Alba I. Zlzzamin, The House Stands Firm: Failly Life in West Africa (Mllwaukle: The Bruce Publishing Co., 1962), p. 79. 
On the night that the girl is brought to the house of the groom, her parents will beat drums and invite their friends and nelghbors to participate in an open feast. The bride's mother will spend most of her time the day before questioning her daughter on whether or not she has been engaging in pre-marital sex. Such intervlews are usually held in smoky rooms and are $11 \mathrm{mited}$ to a few people who are friend's of the bride's family. Considerable importance is attached to a girl's virginity because the traditional African society abhors pre-marital sex. 29 A woman who is guilty of pre-marital sex will not only bring disgrace to herself, but will lose a lot of her friends. In fact, there are instances in which girls are so worrled about retaining their virginity that they will adopt devious and nefarious practices in order to conceal their former sexual involvements.

There is always dancing and drinking on the night that the bride is brought to the groom's home. She will be led to her husband's room at about $8: 00 \mathrm{p} . \mathrm{m}$. by an old woman who will be responsible to certify her virginity. They usually get that information from either the husband or by examining the groom's bed spreadings for traces of blood. While all this maneuvering continues in the groom's room, the bride's parents will wait with anxious suspense outside for a word or sign confirming their daughter's virginity. If they receive a positive reply, the drinking, dancing and drumming will continue at an accelerated pace. 30 If, on the other hand, the answer is negative, all the feasting will

${ }^{29}$ E. R. Langley, "Sierra Leone Studies," Marrlage Customs Amongst the Temnes Chapter 13, (1928), pp. 54-59.

${ }^{30}$ Ibid. 
suddenly cease and the bride's parents w111 return to their home with downcast eyes.

When African women marry, they do not start a famlly of their own. They instead belong to an already constltuted family. This type of situation is made possible by the extended African family system. One of Its most complex characteristics, however, is its polygynous nature. Many western writers do not understand the way polygyny operates and how it is appropriate to the African soclety. For instance, there are several reasons why Africans desire to marry more than one wife. The most obvious and frequently granted reas on is that the possession of several wives reveals a man's economic standard. ${ }^{31}$ In essence, a man's status in the society is not based on the number of cars that he owns, or the amount of stocks he has bought but by the wives he is able to marry and maintain.

Today, the greatest polygynists in Africa are the chiefs, subchlefs and local authorities. Apart from thelr being able to pay for the wedding costs, they also recelve unsolicited wives from their loyal citizens. 32 People who want to be associated with the ruling families in their villages also give up their daughters as wives to these authorities. Furthermore, chiefs are forced to possess several wives because of the various obligations that they are required to satis. fy. For instance, as head of the village, they are supposed to entertain government and out-of-town visitors. Their duties require a large staff. Also according to customary law, Africans are permitted to inherit

${ }^{31}$ Alba I. Zizzamin, The House Stands Firm: Family life in west Africa (M1lwaukle: The Bruce Publishing Co., 1962), pp. 79-95.

$$
32 \text { Ibid, pp. 93-94. }
$$


the wives of their deceased relatives. 33 since the chlefs sometimes have large families, they therefore always end up with a great number of wives to support.

Apart from the above, there are also other reasons why people in the northern part of Slerra Leone practice polygyny. For instance, lack of modern baby foods is an important factor. On many occasions women. nurse their bables for two to three years. During that time, they do not have any sexual contacts with their husbands because they fear that such connection will pollute the milk in their breasts. 34 The only recourse therefore, is for the male to either go without sexual intercourse right through the perlod the wife will be nursing the baby or marry another woman. Many a time, the men select the second alternative. Also, a co-wife is regarded as an effective solution for extra help. In a country where tractors are rare commodities ard mechanized farming is minimal, the possession of many wives will supplement a much needed labor force.

Customary law also permits fathers to select wives for their son and this is particularly common among the Limbes and Temnes in the north. The Moslem religion also contributes to polygyny in Northern Slerra Loone. Since most of its inhabltants are Moslems and their prophet Mohamed allows then to marry more than one wife, many people who belong to that falth become polygynists. For instance, an heir is allowed to marry the widows of the deceased as long as he has the money and is mature enough to keep

$33_{\mathrm{M}}$. McCulloch, Peoples of Sierra Leone (London: International African Institute, 1964), p. 59.

${ }^{34}$ Interview with Adama Kann, October 20, 1972. 
them. Brothers are permitted to marry the widows of their older brothers if they are able to provide them with financial support. 35

The most complicating laws, however, among the tribes of Northern Sierra Leone, deal with the position of the wives. The functions of each wife in a polygynist home are defined by the time in which she was married. Normally, the most important among the wives is the first one. She is referred to as "Mbatheh" among the Temes. She is the Intermediary between the husband and the co-wives. 36 she has absolute authority over them and arbitrates in their disputes. She is also in charge of the house keys and decides what food should be cooked each day. If the husband plans to marry another wife, her approval is always sought before executing the proposal. Her most important and perhaps controversial function however, is to decide each day which of the "1ittle wives" should sleep with the husband. Many polygynist homes have been wrecked because of the selfish tendencles of the senior wives. Many would like to monopolize the husband and thereby force the co-wives to rebel or quit the home. According to customary law, each wife is supposed to spend three nights with the husband and then give way to the other. The first wife, however, is allowed to go to bed with the husband at any time. It is her unrestricted access to the husband that sometimes leads to abuse and vehement opposition from the "little wives". Apart from animosities emanating from the bedroom controversies, polygyny also contributes to many other side effects. The idelicate harmony' existing between the wives is frequently broken by quarrels 35E. R. Langley, "Slerra Leone Studies", Marriage Customs Amongst the Temnes, Chapter 13, (1928), p. 58.

${ }^{36}$ Interview with Adama Kann on October 20, 1972. 
and exchange of fists. Furthermore, the husband's tendency to favor one wife against the other will lead to chaos and a bitter struggle at home. In fact, the success of the home depends entirely on the husband's ability to manipulate his wives and thereby maintain an uneasy noutral position. His problems are compounded if all the wives and their children stay in the same house.

One of the ironies of polygyny however, is that the birth rate is lowered for people who practice it. For instance,

Mogho-Naba Kom, who ruled the Muss 1 at the end of the past century, had 500 wives but only 20 children, all daughters. Mogho-Naba Kom, who died in 1946 had 350 wives and a total of 42 children. The celebrated sultan of Fousam in the Cameroun, Ndojoya, had 147 children despite the fact that his wives at one time numbered $1,200.37$

Most of the wives and children of polygynists either stay in the same village or campus. It is therefore not uncommon to go to towns in the north in which most of the inhabitants are related.

Divorce in the polygynous soclety is long and complicated. According to African tradition, the husband has right over his wife as long as she is alive. Even when he dies, customary law provides that the wife should marry one of his relatives. The most common grounds for divorce however, are impotency, frequently flogging the wife or neglecting to support the parents-in-1aw. 38 The husband also is permitted to divorce his wife on the following grounds: (a) infidelity (b) sterility (c) stealing (d) non-virginity. For each of the above,

37 Alba I. Zizzamin, The House Stands Firm: Family Iife in West Africa (Milwaukle: The Bruce Publishing Co., 1962), p. 96.

38 $\mathrm{E}$. R. Langley, "Slerra Leone Studies", Marrlage Customs Amongst the Temes, Chapter 13, (1928), p. 58. 
the husband may most 11 kely get his dowry refunded.

The problems arising from the return of dowries and the complex marriage laws have forced a number of African countries to carefully examine the institution of polygyny. In Bamako, the government has made it 11 legal for someone to pay a dowry of over $\$ 150.00$. This makes it easy for the parents to return the dowry in case their daughter rejects the husband. In Guinea, President Sheku Toure has abolished forced marriages and made 17 years the legal age for girls to marry. Despite these changes many problems remain to be solved. The parents st111 have the greatest say on the type of person their daughter w111 marry.

The power of the parents over their daughters is enhanced by the exlstence of secret societies. Before the colonial rulers, the Porroh, the Gbangbani and the Bundo had Immense influence in northern Slerra Leone. The first two societies were predominantly controlled by males and they dealt with customary initiation. It is in these societies that the parents are able to shape the future course of their sons' $11 \mathrm{ves}$. There the "young boys" are taught the different roles they are to play in the adult life. They also learn skills, trades and 11 sten to lectures delivered by the elders. ${ }^{39}$ Among the Limbas in the north, membership In the Gbangbani society is an important requirement for anyone interested In becoming a chief, sub-chief, or local authority. In fact, control of the village rests entirely on these members. Anyone who refuses to joln the society faces isolation, and considerable loss of prestige.

$39 \mathrm{M}$. McCulloch, Peoples of Slerra Leone (London: International African Institute, 1964), pp. 29-94. 
In the case of the Bundo Society, which is female control, the girls' perlod of training starts after their first two weeks in the bush. There they are taught how to become good wives and future parents.

They also learn female skills that include cooking, singing and dancing. 40 The initiation period usually lasts for about six weeks after which the initiates prepare for the graduation ceremony.

At that time, parents, relatives and husbands-to-be take part in an elaborate ceremony in which the graduates would be displayed in general sections of the village. They will be allowed to receive presents from the crowd. The ceremonial feasting usually lasts for a couple of days and immediately after the "digbas" and "saimas" will send the young graduates to their different homes. This act marks the end of the traditional education program.

Among the tribes in the north, Western education is regarded with suspicion. They fear that their children will adopt the white man's ways and neglect his African customs. They also feel that the missionary schools teach Africans to despise their elders and hate farm work. People in the north therefore prefer to keep their sons at home and teach them how to become successful farmers. The opposition of Northern tribes to Western values is much more apparent in their attitudes towards female education. Most feel that the educated girls may be difficult to control because of their new Ideas and strange habits which they have acquired in school. They charge that a girl who has never been to school has a better chance of marrying elther a

\footnotetext{
$40_{\mathrm{K}}$. L. Little, "The Changing Position of Women in Sierra Leone,"
} Africa XVIII, pp. $1-17$ 
chlef, a diamond digger, a wealthy trader or some influential person. Despite these obvious setbacks, many of the northern tribes are beginning to change their views and are sending more of their children to school. Already there are over flfteen high schools in the north as opposed to only one high school in 1950. The emphas is on the secret socleties is eroding. The former power of the Porroh, Gbangbani and Bundo socleties are no longer as effective. The more westernized the community becomes, the less emphasis is placed on African tradition and societies.

In effect, the majority of the northern tribes still follow the African customs. There are signs that this is gradually changing. The next part of this paper w111 focus on the effects of increased modernization on young 1 iterate and 1111 terate men and women in the northern tribes of Slerra Leone. 


\section{METHODOLOGY}

The research was conducted in the northern part of Slerra Leone. The seven main tribes in the north are: Fullah, Limba, Loko, Mandigo, Susu, Teme and Yalunka, and all were represented. The three main areas of residence, city, town and village were all taken into consideration in the sampling of the resporidents.

In December 1972, fourteen questions wore drawn up in the form of a questionalre with flxed and open ended response and were given to one hundred college age respondents. The college age group in this paper was defined as ages 19-30. The groups were divided into two main groups viz, educated and uneducated and four subgroups which included Mus 11m and Christian females and males. Twenty-five questionalres were glven to each educated or uneducated male and females. Because of the unequal division of Christians and Muslims residing in the north, an equal number of representation of these religions was not feasible.

Four words were used interchangeably in this research. The word educated or 1 iterate refers to those respondents with formal western education of schooling from class one (first grade) to the defined college age. The uneducated or 1111terate refer to those with or without Arablc or western formal education.

Fifty questionaires were given out to literate male and female Christians and Muslims to be filled out by themselves. The other fifty were completed through face to face interviewing technique by the researcher. Terme and Creole which are the two commonly spoken languages in Slerra 
Leone as whole and were used during the interviews. During rare instances when a respondent was not able to communicate using one of these languages, 11terate interpreters were used to interpret the questions to the respondents.

The aim of the research was to ascertain the attitudes of college age young people, reflecting the intergenerational changes from traditional values. The underlying purpose was to understand the direction of change and distribution of attitudes for soclal planning and dealing with people and their social problems from the perspective of social work. Independent variables were sex, religion and education, with age group and residence and religion held more or less constant. Dependent variables were focused around famlly $11 \mathrm{fe}$, since that institution is central. Economic, educational and family values were elicited as dependent variables.

Time avallable, complexity of village distribution and traveling difficulties made a random sample unfeasible. Therefore, a selected sample based on the independent variables was used.

Analys is of the data is in the form of summary tables which report the question, the different values and the contrasting independent variables with comments. Measures of statistical inference seemed inappropriate. 


\section{ANALYSIS OF RESEARCH DATA}

In this section, the values of the college age population will be presented in tabular form, followed by comments. Table titles reflect modal findings. The question to which they responded will be stated. Subheadings give the independent variables and the stubs give the dependent variables, that is, the values to which they were responding, in the form of preferences or choices. Numerical values show the number of persons within the categorles who made the indicated cholce.

Many differentiations and relationships appear in the tables not singled out for comment, but are presented for the readers own purposes. Respondents' verbal and open-ended responses were used in the commentary, as well as the researchers native familiarity, wheh necessary for understanding reactlons.

\section{TABLE Ia}

THE EDUCATED PREFER EDUCATED SPOUSES

Question: Which of the following would most likely influence your cholce of a wife or husband?

EDUCATED:

a. Religion
b. Education
c. Tribe
d. Some town or area

No Response

\section{CHRIST IAN}

Male Female

$5 \quad 1$

89

01

20

01
MUS LIMS Male Female

133

48

130

$\begin{array}{lll}0 & 0 & 1\end{array}$

100 
TABLE Ib

THE UNEDUCATED PREFER TRIBAL SPOUSES

\section{UNEDUCATED:}

a. Religion

b. Education

c. Tribe

d. Same Town or Area

No Response

\section{CHRISTIAN} Male

3

0

4

3

0
Female

1

0

4

0

0
MUSLIMS Male Fenale

\section{5}

0

7

3

0
8

1

8

2

1

In this question, the respondents were asked to indicate which of the following: religion, education, tribe, same town or area, would most 11kely influence their cholce of spouse. Most of the oducated Christians and Musilms chose education as a main factor in their cholce of a spouse. While the uneducated respondents chose spouses from their tribes or places of residence, the new western commonality amongst the educated, proved to be more overpowering in attracting couples, as opposed to the traditional method of considering cultural groups for a spouse, because they "speak the same language". Because of the influence of education, the respondents do not feel bound to communlcate just through their tribal language; instead other forelgn languages taught in schools can be substituted to carry out communication that would have bound them to marry in the traditional way. 
TABLE IIa

NORTHERN TRIBE'S CHOOSE SPOUSE THEMSELVES

Question: Whorn do you most prefer to choose your spouse?

EDUCATED:

CHRISTIANS
Male MUSLIMS
Female Female

$\begin{array}{lcccr}\text { a. Friends } & 3 & 0 & 2 & 0 \\ \text { b. Parents } & 0 & 2 & 2 & 0 \\ \text { c. Self } & 10 & 10 & 5 & 11 \\ \text { d. Other } & 2 & 1 & 1 & 0 \\ \text { No Response } & 0 & 0 & 0 & 0\end{array}$

TABLE IIb

NORTHERN TRIBE'S CHOOSE SPOUSE THEMSELVES

UNEDUCATED:

a. Friends

b. Parents

c. Self

d. other

No Response

CHRIST IANS
Male Female

10

4

5

0

0
MUSLIMS

Male Fernale

2

3

7

7

3

0

In this question, the respondents were asked to indicate the person they would most prefer to choose their spouse for them. The responses made in this question showed that all the respondents, with 
the exception of the uneducated Musilm male and the uneducated female groups would more prefer choosing for themselves.

The diversion of the educated respondents to choose their spouses thems lves, as opposed to the traditional role of the parents' choosing st111 seems to Indicate the influence of education in their desire to discontinue some of the traditional expectations.

The period of time when the uneducated male can stay in his parents' home is not determined by marriage. Far often, young men at the age of 16,17 , or 18 , leave their homes for the cities or the diamond fields at Kono. Generally they stay in these flelds elther as 1111cit diamond diggers or engage themselves in some odd job around the town. In spite of this independence from their home, either by employment or as a "city drifter", their religlous tles have not been broken and they have remained committed to their traditional and religfous patterns. It is not surprising to see the uneducated male more committed because the Musilm falth requires more male involvement than female.

While the uneducated female indicates an equal split of responses between self and parents, it shows they are slowly but certainly working through some of their mixed feelings as to whether to choose for themselves or to carry on with the tradition of allowing the parents that honourable privilege. This gradual change tends to reflect western influences. Traditionally, females in African homes spend a longer period in their parents' homes than do the males. Their stay under this parental control is almost indefinite, especially if they are unable to get someone to marry them. Consequently one would 
expect them to have a greater degree of parental obedience than the male.

Like males who leave home for school or job, the educated femalo groups gain their independence of Individual thinking from experiences of belng away from home while attending high school or college, as opposed to the uneducated. Also, their cholce of choosing a spouse by themselves was justifled as a way of freeing themselves from blaming others. If the marriage falls to work out, then they would like to see it as their fault, because they themselves would have simply failed to work a little harder at a successful marriage. The conclusions from their responses seem to indicate some degree of western and educational influences on the respondents' unenthuslastic ambition to continue the traditional marriage customs. 
TABIE IIIa

NORTHERNERS TO RESIDE WITHIN TRIBAL AREA

\begin{tabular}{|c|c|c|c|c|}
\hline \multirow[t]{2}{*}{ EDUCATED: } & \multicolumn{2}{|c|}{ CHR IST IANS } & \multicolumn{2}{|c|}{ MUSLIMS } \\
\hline & Male & Female & Male & Female \\
\hline a. at father's house & 0 & 1 & 1 & 1 \\
\hline b. with other relatives & 2 & 5 & 1 & 3 \\
\hline c. near father's house & 2 & 3 & 1 & 2 \\
\hline $\begin{array}{l}\text { d. In tribal area, but } \\
\text { (not } a, b, \text { or c) }\end{array}$ & 4 & 2 & 7 & 5 \\
\hline No Response & 4 & 2 & 0 & 1 \\
\hline
\end{tabular}

TABIE IIIb

NORTHERNERS TO RESIDE WITHIN TRIBAL AREA

UNEDUCATED:

CHRISTIANS
Male MUSLIMS
Male Female

a. at father's house

6

1

7

6

b. with other relatives

0

0

1

2

c. near father's house

2

1

4

2

d. In tribal area, but not

$$
(a, b, \text { or } c)
$$

2

0

2

8

No Response

0

3

1

2

in question three, the respondents were asked to indicate where they would prefer to $11 \mathrm{ve}$ when they get married. Here again, most of the educated Muslims and Christian male respondents preferred to 1 ive 
within the tribal areas. In sharp contrast to their views, the uneducated males from both religions, would prefer to live in their father's house. Interestingly enough, the females split on this question. The educated Christian females prefer to live with other relatives while their Muslim counterparts chose the tribal areas. The uneducated Christian females wished to stay in their husband's houses wherever they may be, while their Musim counterparts preferred to 11ve in tribal areas. In the male no-response group, they merely indicated a willingness to live wherever they could find employment and feel comfortable.

This question reveals interesting conclusions. Left with no sultable alternative, educated Christian and Mosilm male respondents prefer to maintain some independence by staying in a tribal area rather than near their relatives. The women on the other hand, were different. Although as literates, one would expect them to be slightly broad minded, yet they chose to live in the houses of their relatives rather than stay independent. Besides the fact that the women's dependency is generally more acceptable, staying alone by herself is discouraged and looked upon disapprovingly by the public because such women are usually accused of practicing prostitution, an allegation that is almost non-existent in the case of men. 


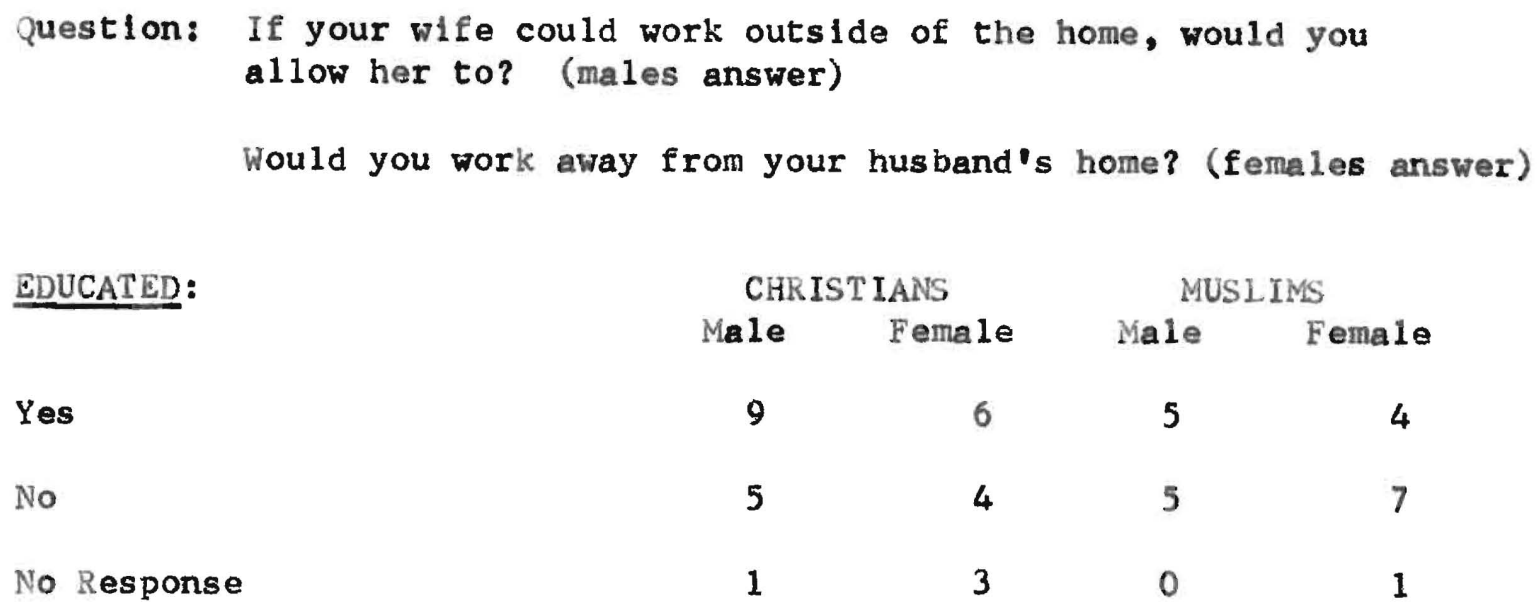

TABLE IVb

WIVES WOULD WORK OUTS IDE THE HOME

UNEDUCATED:

Yes

No

No Response

\section{CHRIST IANS}

Male Female

5

4

1

5

4
4

0

1
MUSLIMS Male Female

11

9

4

11

0

In question four, the respondents were asked to indicate whether the male would allow their wives to work outside the home or If the women would accept employment outside of the home. On both of these issues the educated and uneducated groups, all but the female Muslims would allow or accept outside employment. One explanation for the difference in response between the two female religlous groups could be that Mus $1 \mathrm{~m}$ females are generally brought up in an atmosphere of 
obedience for religion, parents (nuclear and immediate family) and husband. Since the act of working away from home symbolizes an act of attempting to equate theinselves with their husbands, this would therefore be contrary to their beliefs. The intervlewed uneducated Musim women precisely saw their roles as staying home and cooking for the family and taking care of the children. 
TABLE Va

PARENTS TO SETTLE DISPUTES

Question: If you and your spouse(s) should have a quarrel, who is most likely to settle your dispute:

EDUCATED:

\begin{tabular}{ccc} 
CHRISTIANS & \multicolumn{2}{c}{ MUSLIMS } \\
Male Female Male & Female
\end{tabular}

$\begin{array}{lllll}\text { a. Parents } & 9 & 7 & 7 & 9 \\ \text { b. Other relatives } & 4 & 5 & 2 & 3 \\ \text { c. Native Court (chief) } & 1 & 0 & 0 & 0 \\ \text { d. Civil Court } & 0 & 0 & 0 & 0 \\ \text { No Response } & 0 & 0 & 1 & 0\end{array}$

TABLE Vb

PARENTS TO SETTLE DISPUTES

UNEDUCATED:

a. Parents

b. Other relatives

c. Native Court (chief)

d. Civil court

No Response

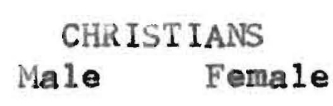

6

1

2

1

1
4

0

1

0

0
MUSLIMS Male Female

$0 \quad 3$

$0 \quad 0$

$0 \quad 0$

$0 \quad 1$

The respondents were asked to state the person or institution that would settle their disputes. In this question, the traditional role of the parents (either patriarchal or matriarchal) to settle unresolved arguments between spouses was indicated. Although parental 
control and African tradition is being challenged in Northern Sierra Leone, by Western influence and education, yet their roles seem to remain viable and effective. Regardless of the respondent's religion, sex or educational status, the role of the famlly as an intervener during a family crisis was held quite highly. Other family members were chosen as second place to settle marital disputes, over the native or civil courts which would involve other members outside of the family unit. 
TABLE VIa

REASONS FOR DIVORCE

Question: What would cause you to seek a divorce?

EDUCATED:

CHRISTIAN

Male

Unfaithfulness

No respect for parents

Can't compromise

Unfaithfulness

Ungratefulness

Dislike or death

MUSLIM

Male

Disobedience

Unfaithfulness

Disputes and egocentrism

Female

Foma le

Unfaithfulness

Rlotous Living (Gambling)

Ungratefulness

TABLE VIb

REASONS FOR DIVORCE

UNEDUCATED:

CHRISTIAN

Male

Female

Unfaithfulness

Lack of Respect for parents

and Friends

Disobedlence or death

Hus band's choice

Ungratefulness

Neglect of children

MUS LIM

Male

Fenale

Unfal thfulness

Unfaithfulness \& ungratefulness

Disobedi ence

Wife's cholce, death Hus band 's cholce or death No respect for parents 
These answers are in order of frequency of multiple responses. They did not indicate too much difference in reasons for divorce. The majority of the respondents chose unfalthfulness or attempting to have a secret affair with someone other then the husband or one of the husband's wives. This answer reveals the deep-seated opposition that northerners have against adultery. In an area where polygyny is common and accepted, one would expect more relaxed feelings towards adultery. But on the contrary, having an affair outside of the marriage seem to be highly disapproved by both the 11 terate and 1111 terate respondents. Ungratefulness, for the purpose of this paper is defined as exploitation and manipulation of one partner until a certain desired goal is attained. Afterwhich, the partner looses his importance in the marriage as a partner. A typical example given was saving money to start a business. Following the success the husband might 80 and marry a much younger and attractive wife to run the store. For the first wife, this is ungratefulness and can result in a divorce especially If she has been totally neglected.

Because of the close extended family relationships in Northern Sierra Leone, lack of respect for parents of either side, could be reasonably considered as a good enough reason for divorce. 
TABLE VIIa

EQUALITY FOR CHRISTIANS

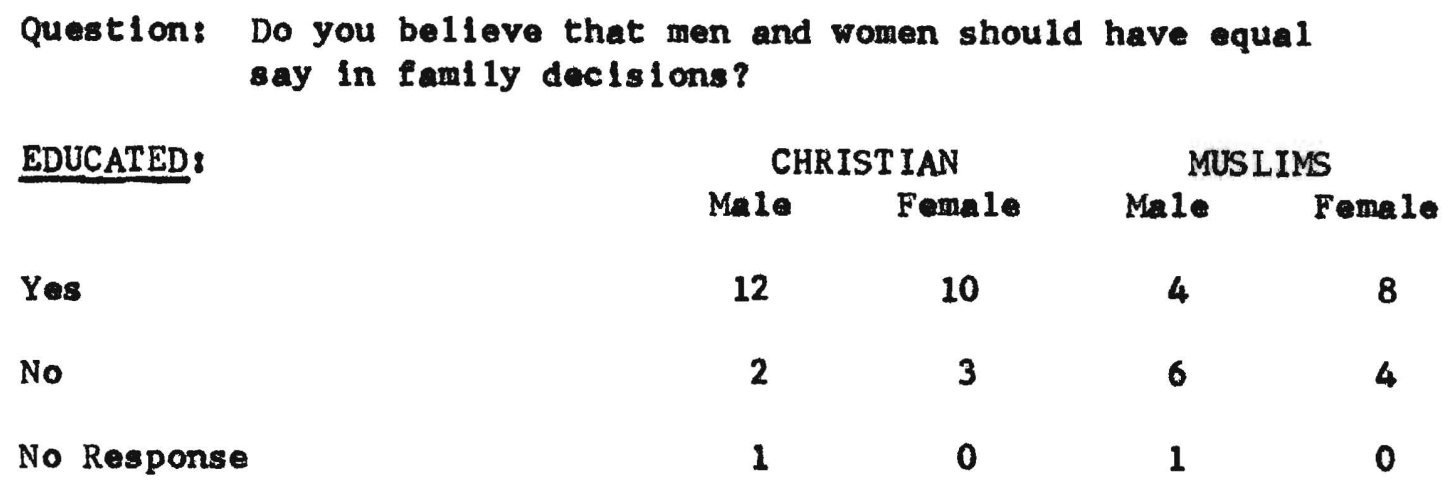

TABLE VIID

INEQUALITY FOR UNEDUCATED

UNEDUCATED:

Yes

No

No Response

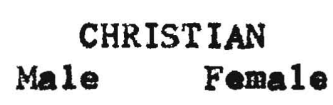

3

7

0
2

3

0

\begin{tabular}{cc}
\multicolumn{2}{c}{ MUSLIMS } \\
Male & Female \\
5 & 9 \\
10 & 11 \\
0 & 0
\end{tabular}

In this question, the respondents vere asked to say if mon and women should have equal say in family decisions. With the exception of the educated Christian males and females, the rest of the groups tended to feel that a man should have greater say in famlly declelons than the woman. In this question, we can detect the influence of education and religlous teaching. While more Christlans thought it expedient to consult their wives or husbands before reaching a decision, 
the Musilms with thelr strong bellef in the humble or inferior role of the wife, responded accordingly. Education in this instance has had 1itt le effect on them. Also an analysis of the responses show that the iliterate are more reluctant to give greater powers to the women than the literate respondents. The uneducated respondents from the both religlous groups rejected the idea of sharing decision making at home with their wives.

Nevertheless, a great number of the respondents were aware and expressed the reality of modification of some traditional practices that are slowly taking place. The majority of them would answer the question by saying "equality is not customary, but things are chang ing". 
TABLE VIIIa

REASONS FOR MONOGAMY

Question: What would your main reas on be for not being in a polygynous marriage?

EDUCATED:
Male

MUS LIM

Male

Fomale

Social, economic

Quarrels in the home

Jealousy amongst members

Fomale
Jealousy amonst parents -
children
Quarrels in the home
Husband's unfairness

TABLE VIIIB

REASONS FOR MONOGAMY

UNEDUCATED:

CHRIST IAN

Male

Quarrels in the home

Religion

Financlal
Fomale

Quarrels in the home Competition Husband's unfalrness of love

MUSLIM

Male

No reas on
Fomale

Quarrels in the home No reas on Hus band's Unfairness of love 
Respondents were asked to give reasons why they would not want to be from a polygynous home. All the groups, with the exception of the uneducated Muslim males, 11sted jealousy among children and parents, quarrels in the homes, competition, unfalrness of the husband's love for the parents and chlldren and the lack of trust amongst parents. Consequently, only the educated Christian males and females, and the uneducated Christian males gave religion as a reason for not wanting to continue the traditional polygynous family style practices. The malntenance of the family, as it relates to educating the children was also one of the given reasons. This concern brings out the present aspirations of Northern Slerra Leone families to provide Western education to their chlldren and something much more than they ever had. The uneducated Muslims had no reas on why they would not want to have a polygynous home. This response also goes to explain their religlous practices of four or more wives as being an acceptable way of life for them. 
TABLE IXa

CHARACTERISTICS FOR A SPOUSE

Question: In the order of prlority, which characterlstics do you
look for in selecting a spouse?

EDUCATED:

CHRISTIAN

Male

Female

Good Character

Beauty

Education

Education

Religion

Ambitions

MUS LIM

Male

Female

Good Character

Beauty

Edueation

Education

Good Character

Ambition

TABLE IXb

CHARACTERISTICS FOR A SPOUSE

UNEDUCATED:

Male

Beauty

Good Character with respect

Religion

MUSIIM
CHRIST IAN
Fenn 10

Ambition and love

Good Job, education

Falthful

\section{Fomale}

Good Character

Good Family Relations

Religion and Handsomeness

Good Character

Co-operation \& Obedience

Beauty and $K$ indness 
In this question, the respondents were asked to 11 st in their order of priority, three characteristics they look for in selecting apouse. In the flrst order, the educated Christian and Mus IIm males, uneducated Muslim males and females would all choose good character. Good character in this paper was defined by the respondents as "obedience" and respect for both side of parents and friends. Their cholce of good character, reflects the concept of extended family relationships, upon which Northern Slerra Leone operates. If a wife is not friendly and does not accept other family members who often stop in for temporary stays and if she allows animosity to creep in, such relationshlp could create problems which lead to a divorce. The other choices between the second and third varied from ambition, love, good famlly background relationships and cooperation, good looks and education.

In spite of the gradual Influence of education and Western way of viewing things, with the exception of the educated Christians, all the groups seem to consider the traditional "good" qualities for a sultable spouse. 
TABLE Xa

MALE BABIES PREFERRED

Question: How many children would you prefer (glrls and boys)?

CHRIST IANS

75

67

142
MUSLINS

83

65

148

In regard to this question, the respondents were asked to state how meny chlldren they would like to have, indicating the number of boys and girls. This question reveals that both Christlans and Muslims prefer producing more boys than girls. This in essence shows that although Westernization has had some influence in the North, most of its inhabitants still want to perpetrate the old African custom of showing preference for males over females. Also, the research reveals that both Christians and Muslims have almost the same desire for large families. 
TABLE XIa

EDUCATED PREFER BIRTH CONTROL

Question: Do you or would you use birth-control devices?

EDUCATED:

Yes

No

No Response

CHRISTIANS
Male Female

12

3

0

2

0
MUSIIMS

Male Female

610

31

11

TABLE XIb

ONLY UNEDUCATED FEMALES PREFER BIRTH CONTROL

UNEDUCATED:

Yes

No

No Response

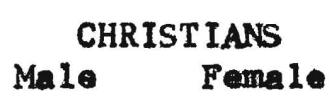

3

7

0
4

1

0

\begin{tabular}{cc}
\multicolumn{2}{c}{ MUSLIMS } \\
Male & Female \\
4 & 11 \\
11 & 9 \\
0 & 0
\end{tabular}

This question deals with whether they will use birth-control devices. The educated Christian males and fomales said yea. Their positive reply is probably due to their exposure to Western influence and education and the economic burdens of having more than one wife. Most of those who responded seemed to press the economic difficulties rather than the tribal requirement. But on the contrary, the 1111 terate respondents from the two religious groups replled in the negative because of their religlous convictions. These Muslims and the Christians 
both believed that it was unethlcal and irreliglous to use birth control pills. The only surprise came from the 1111 terate fenale respondents in both religlons. All consented to use birth control devices only after they have produced the deslred number of children. In an environment where males are regarded higher than females, husbands whose wives produce fomales consistently never reach the "desired goal" unt11 they have boys. Th1s process will increase the number of children and lessen the use of blrth control devices. 
TABLE XIIa

LESS EDUCATION REQUIRED OF FEMALE SPOUSE

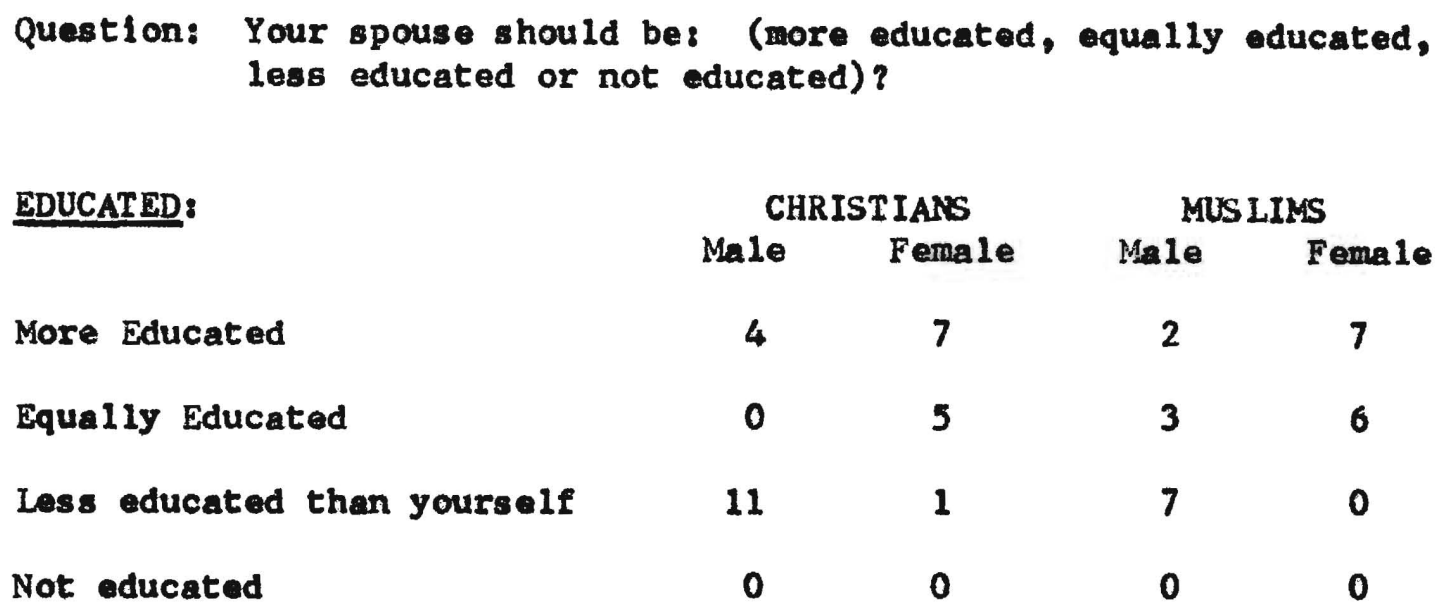

TABLE XIIb

LESS EDUCATION REQUIRED OF FEMALE SPOUSE

UNEDUCATED:

More Educated

Equal1y Educated

Less Educated than yourself

Not Educated

No Response

\begin{tabular}{cccc}
\multicolumn{2}{c}{ CHRISTIANS } & \multicolumn{2}{c}{ MUSLIMS } \\
Male & Fomale & Male & Fomale \\
2 & 0 & 0 & 13 \\
2 & 3 & 6 & 4 \\
4 & 1 & 9 & 0 \\
2 & 1 & 0 & 3 \\
0 & 0 & 0 & 0
\end{tabular}

An analysis of the answers from this question confirms once again the greater role of the male in the traditional Northern Sierra Leone family home. Most of the males from both religlons feel that they hould be more educated. Such a situation will give them the opportunity to fulfil their role of the traditional malo in the home as the head 
and superior over the female. Most of the respondents also indicated that a wife who is more educated than the husband may take up insubordination and undermine the position of her man. Naturally, these simplistic conclusions from the men show a continuous trend of their unwilingness to grant complete equality at home with their wives. The women on the other hand seem to accept this situation as a natural falt accomp11. Although a few vere unable to say why it should be so, the majority seem to imply that the more educated a woman becomes, the amaller her chances of getting a husband becomes, since this education might automatically put her in a superior role over the man. Simplistically, therefore, the women in past years have been more satisfied to stay at home and fulfil their prescribed roles as housekeepers and mothers, rather then to compete in offlces and other working areas with their husbands. 
TABLE XIIIa

PREMARITAL SEX ACCEPTABLE ONLY FOR MEN

Question: Do you think that promarital sexual otandards should be the same for men and women?

EDUCATED:

Yes

No

No Response

\begin{tabular}{cccc}
\multicolumn{2}{c}{ CHRISTIAN } & \multicolumn{2}{c}{ MUSLIMS } \\
Male & Female & Male & Female \\
4 & 5 & 4 & 0 \\
11 & 8 & 8 & 7 \\
0 & 0 & 0 & 0
\end{tabular}

TABLE XIIIb

PREMARITAL SEX ACCEPTABLE ONLY FOR MEN

UNEDUCATED:

Yes

No

No Response

\begin{tabular}{cccc}
\multicolumn{2}{c}{ CHRISTIAN } & \multicolumn{2}{c}{ MUSLIMS } \\
Male & Female & Male & Female \\
4 & 0 & 3 & 7 \\
6 & 5 & 13 & 13 \\
0 & 0 & 0 & 0
\end{tabular}

Despite the Elssures, all the respondents from both rellglons with the exception of the educated Christian females, belleved men should have nore laxity in this issue than women. The positive answers seem to follow the same trend of putting the male on a higher scale than the female. These feclings do not appear to have been radically altered by Western influence whlch supports equality between the two sexes. Most of the people who responded to the question felt that the soclety Indirectly permits ale to have an affair with another 
woman besides his wife while the woman is expected to play the submissive role of one woman for one man. In supporting this argument, the iliferate respondents think that since men are not required to maintain their virginity to the time of their marriage it can therefore be assumed at polnt as being right for them to have an affair with another woman before that time. But this argument was sharply opposed by the educated Christian women who demanded that the standards for premarital sex should be the same. Here we are beginning to notice the spirit of Independence among the educated class manifested in a atronger way. If this kind of attitude continues, it might lead to an imperative alteration of the women's role in Northern Sierra Leone families. 
TABLE XIVa

VIRGINITY NOT REQUIRED FOR EDUCATED

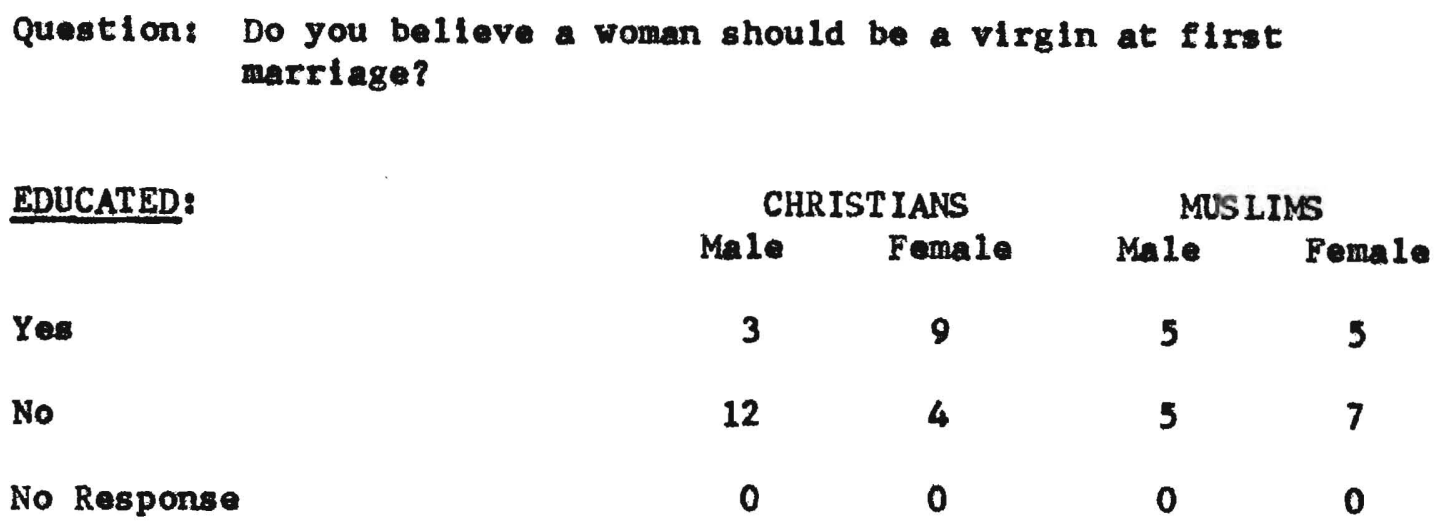

TABLE XIVb

VIRGINITY REQUIRED FOR UNEDUCATED

UNEDUCATED:

Yes

No

No Response

CHRISTIANS
Male Female

6

4

0
3

2

0

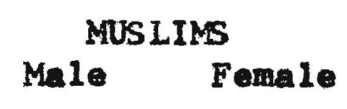

15

0

5

$0 \quad 0$

In this question, with the exception of the educated Christian males and Musilm females, all other groups said yes predominantiy. There was, however, a split anong educated Muslim males. One half answered in the affirmative, the other in the negative.

Once again, we see the exaltation of the man on a higher scale in something of extreme importance. The greater degree of freedom that is acknowledged to men, as opposed to women, was also evident. The answers also implied that although Western influence is permenting 
rapidly among the Northern tribes, yet it also indicates that there are strong remants of tribal customs. Virginity among the Northern tribes seems to be an expectation from a woman at her first marriage. This subject, In past years had a great influence in determining the success or fallure of a marrlage. But, as the answers of the educated Christian males and Musilm fomales show, there may be some erosion of African customs. 


\section{CONCLUSIONS}

An analysis of the questions and answers discussed, indicated that the inhabitants of the Northern part of Slerra Leone may be changlng their social customs as a result of their being consistentiy exposed to Western and missionary influence. This change 1s, however, occuring at a slow pace. With the exception of a few, the attitude of the educated men in the North towards marrlage is mainly "nativen. Despite the impact of Western culture through the opening of schools and churches, men still maintain supreme control over women. The husband is still regarded as the head of the family and most of the major decisions are reached by him. Interestingly enough, there is 11ttle attempt at challengling the absolute position of the males. With the exception of a few cases in which some women express the desire to have equal rights with men (see Q. vIIa, female Musilm) the rest belleve that it is proper for men to be estimated on a higher scale than themselves. For instance, the majority of the women interviewed agreed that men should be more educated than themselves. They also maintained that when it comes to premarital sex requirements, a man should be given greater options than the woman. This obvious attribution of the higher position to the male is unlike some Western societies.

At an age when most women in European countries are striving for equality with men, it is notable that there are some in Africa who want to continue their ancient roles of "producers of chlldren" and 
"preparers of food" for thelr husbands.

Another important conclusion that comes out of this study is that the religlous differences between the Christians and the Musilms are minimized by education. In other words, what appears to be the main issue here is not religion but Western educational experience. In almost case after case, all the male respondents from the two rallgious groups gave similar answers to the questions.

It is equaliy signifleant to note an "adverse" effect that education is having on the Northerners, especially the males. For instance, this study reveals that the more someone becones educated, the less he is committed to tribal ways and customs. This 18 demonstrated by the fact that most of the male respondents showed a spirit of independence on crucial questions. Many preferred to live alone after marriage rather than stay with their parents as is usually the case in African traditional soclety. Also, educated fomales exhibited little independence while a few challenged the overwhelming dominance of the males over the females. The group that showed the least detachnent from the tribal home was that of the 1111terate males and fomales. They supported staying close to their parents and hardly questioned the predominant role of the men. When asked what would most 11kely inf luence their cholce of a husband or wife, they selected tribe over education, religion and nearness of towns.

The study reveals that most of the respected Northern Slerra Leone traditional practices have some dissenters affected by the inpact of Western Culture. 
Marriage, which was an important African institution is now being patterned in the Western fashion. The parents no longer possess their original position as selectors of wives for their children. AccordIng to the research findings, most of the respondents, especlally the unmarried ones, preferred to select their own spouses. Their rationale behind this, they said was to free themselves from blaming others when things don't go exactly the way they should. Moreover, the emphas is on virginity among Northern women is eroding. Before, the majority of girls at first marriage were expected to be virgins. Fallure to be 80 , would have led to disgrace and even divorce. Although there are still many parents who feel a girl should be a virgin until she marrles, that conclusion is not unchallenged, especially by the educated women.

Furthermore, polygyny has been an integral practice of the inhabltants of the Northern part of Slerra Leone for a long time, but the research reveals that this is no longer true. Literate Northerners now prefer to marry one wife rather than two or more. Many of the respondents Interviewed expressed concern about the economic burdens imposed on anyone who decides to marry more than one wife, plus endless quarrels that tend to create animosity among members of the family. They therefore preferred to abandon the African tradition of possessing plural wives for the European concept of one man, one wife.

Presently the research seems to reveal that some Western Influence is slowiy drifting in and affecting most of the college educators. In order for Northerners to take a decisive step on whether to encourage this, and how much to encourage and which ones to encourage and when 
to encourage these changes necessary steps must be taken. The first step would be to encourage the teaching of Afrlcan soclal studies in high schools, teachers colleges and universities. The pupose of these studies would be to discuss the pros and cons of the two cultures, so that Individuals would become more aware of the choices they would be making.

More research should be conducted to provide information about the people of the North. The avallablilty of this information would not only serve as documented material for history, but as a reference for other cultures. In this way, we would have shared our tradition as well as having taken on other Western or modern ways. Soclal pollcy and action must take into account the religlous, sex, educational and other differences in the population, and the impact both of traditional and changing views and practices. 
Allridge, T. J. 1901. The Sherbre and 1ts Hinterland, (London: Macml11an \& Co. Ltd.), 165-281.

Bourne, H. R. F., "slerra Leone Troubles", Fortune, IXX, 226.

Fyfe, Christopher 1962. A History of Slerra Leone, (London: Oxford University Press), $1-580$.

Hargreaves, J. D. 1956. "The Establishment of the Slerra Leone Protectorate and the Insurrection of 1898". Cambridge Historical Journal, XII, 63-68.

Kann, Adama. Interview of October 20, 1972.

Kreutsinger, Helga 1966. The Er1 Devils in Freetown, Slerra Leone, (Elgenverlag-wien: Osterreichische Ethnologlsche Gessellschaft)

Kup, A. P. 1961. A Hlstory of Slerra Leone, (Cambridge: The University Press), 1-100.

Langley, E. R. 1928. "Marriage Customs Amongst the Temes", Slerra Leone Studies, XIII.

Lew1s, Roy 1954. Slerra Leone, A Modern Portrait, (London: Her Majesty Stalemann office).

Little, K. L. 1948. "The Changing Position of Wowen in Slerra Leonen, Africa, (International African Seminar) XVIII, 1-23.

Little, K. L. 1964. "Att1tudes Towards Marrlage and the Famlly Among Educated Young Slerra Leoneans", The New Elites of Troplcal Afrlca, (International African Seminar), 1380162.

McCulloch, M. 1950. Peoples of Sterra Leane, (London: International African Institute), 1-95.

Newland, Osman 1969. Slerra Leone, Its People, Products and Secret Socletles, (New York: Negro University Press).

Poterson, John 1969. Province of Freedom, (Evanston: Northwestern University Press), 27-28.

Roberts, G. T. 1946. Welfare Casework in Slerra Leone", The West African Reviev, XVII, 1363-1365. 
Rotberg, Robert and All Mazru1 1970. Protests and Power In Black Africa, (New York: Oxford University Press), 172.

Sibthorpe, A. B. C. 1971. The History of Slerra Leone, (New York: Humanities Press), 125.

Slerra Leone Royal Garette, August 1896.

S1say, Hassan 1972. "Review of Llberla by Charles M. W11son", Journal of Negro History, LVII, 49.

Zlrzania, Alba I. 1962. The House Stands Firm: Family Life in West Africa, (Mllwaukie: The Bruce Publishing Co.) 